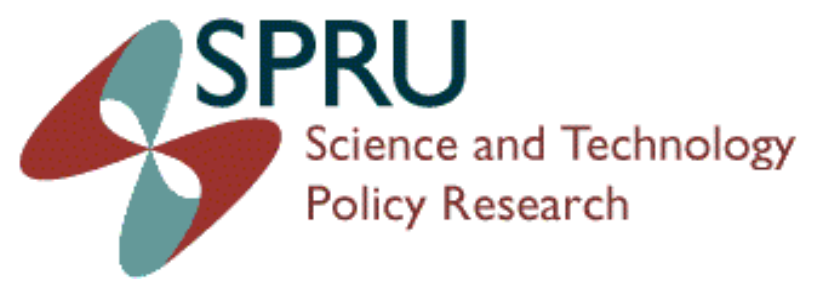

Working Paper Series

SWPS 2013-15

(Research Note)

December, 2013

Schumpeter's Theological Roots?

Harnack and the origins of creative

destruction

Paul Nightingale 


\section{SPRU Working Paper Series}

The SPRU Working Paper Series aims to accelerate the public availability of the research undertaken by SPRU-associated people of all categories, and exceptionally, other research that is of considerable interest within SPRU. It presents research results that in whole or part are suitable for submission to a refereed journal, to a sponsor, to a major conference or to the editor of a book. Our intention is to provide access to early copies of SPRU research.

\section{Editors}

Tommaso Ciarli

Daniele Rotolo

\section{Associate Editors}

Florian Kern

Paul Nightingale

Matias Ramirez

Joe Tidd \&

Carlos Sato

Maria Savona \&

Mariana Mazzucato

Andrew Stirling Transitions

Caitriona McLeish

Civil military interface

Area

Energy

\section{Contact}

T.Ciarli@sussex.ac.uk

D.Rotolo@sussex.ac.uk

F.Kern@sussex.ac.uk

P.Nightingale@sussex.ac.uk

Matias.Ramirez@sussex.ac.uk

J.Tidd@sussex.ac.uk

C.E.Y.Sato@sussex.ac.uk

M.Savona@sussex.ac.uk

M.Mazzucato@sussex.ac.uk

A.C.Stirling@sussex.ac.uk

C.A.McLeish@sussex.ac.uk

J.Lieu@sussex.ac.uk

Administrator

Jenny Lieu

\section{Disclaimer}

The works available here are the responsibility of the individual author(s) and do not necessarily represent the views of other SPRU researchers. As matters of policy and practice, SPRU does not endorse individual research contributions.

\section{Guidelines for authors}

Papers shall be submitted in pdf or Word format. They should contain a title, an abstract, and keywords. Papers should be submitted to one of the Editors, who will process them and send them to the appropriate Associate Editor. Two members of SPRU will be asked to provide a short written review within three weeks. The revised versions of the paper, together with a reply to the reviewers, should be sent to the Associate Editor, who will propose to the Editors its publication on the series. When submitting the authors should indicate if the paper has already undergone peerreviewing, in which case the Associate Editors may decide to skip internal review process.

\section{Website}

SWPS: www.sussex.ac.uk/spru/research/sewps

IDEAS: ideas.repec.org/s/sru/ssewps.html 


\title{
Schumpeter's Theological Roots? Harnack and the origins of creative destruction.
}

\author{
Paul Nightingale, SPRU, University of Sussex, UK \\ p.nightingale@sussex.ac.uk
}

\begin{abstract}
This short research note highlights the similarity between Schumpeter's theory of creative destruction and the work of his contemporary, the German theologian Adolf von Harnack (1851-1930). The note provides a brief over-view of Harnack's concepts and terminology and highlights their similarity to Schumpeterian ideas about routinisation, charismatic entrepreneurial leadership, and creative destruction. While the evidence is far from conclusive it does suggests that the similarity merits closer attention that could potentially lead to changes to the received understanding of the theory of creative destruction. In particular, it suggests a need to potential reassess the position of Schumpeter within a wider Weberian tradition.
\end{abstract}

Keynotes: Schumpeter, Harnack, Qutb, creative destruction 


\section{Introduction}

While there is little interaction between theology and social science today, this was not the case in the early $20^{\text {th }}$ century when Schumpeter wrote many of his major works. The liberal theology movement of the $19^{\text {th }}$ century drew heavily on Enlightenment, and particularly Kantian, ideas and used methodologies from the social sciences to illuminate theological questions (Hagglund, 2007; Harnack, 1988). Similarly, before the disciplinary boundaries of the social sciences stabilised in the early $20^{\text {th }}$ century theological theories often had a direct impact on social science (Taylor, 2002; Draper, 1998).

One of the leaders of this intellectual cross-over was Adolf von Harnack, a prominent German theologian who worked for most of his career at the University of Berlin (1889-1921) having previously worked in Leipzig (1874) Giessen (1879), and Marburg (1886). Harnack was a major international scholar and produced an output of over 1650 books, reviews and essays. As part of the German liberal theological tradition he drew on Enlightenment ideas and scholarly methods, and the previous Biblical criticism of D. F. Strauss, Albrecht Ritschl and Schleiermacher, to distinguish between the teachings of Jesus and Church writings on Jesus. His aim was to uncover the real meaning of Christianity, which he argued had been corrupted by the influence of Greek philosophy. For Harnack, Strauss, Ritschl and Schleiermacher, the Bible was not an expression of timeless truth but a product conditioned by the historical context in which it was produced. Over time new translations and editing had increasingly diluted the original religious meaning as the Bible was adapted to new environments. In a series of works Harnack aimed to rediscover the original sources and editions of religious texts in order to better understand the history of doctrine. By doing so, he aimed to better understand what the unchanging core of Christianity consisted of, and what aspects of received wisdom was misleading historical baggage.

Harnack's religious history was extremely influential in the late $19^{\text {th }}$ and early $20^{\text {th }}$ centuries, as would be expected from one of the senior academics in one of the top universities in the world (Rumscheidt, 1988). His influence was not just academic, as his 'What is Christianity?' was an international bestseller and went through multiple editions in many languages. One of his most influential academic works was The History of Dogma (1886-89; 4th ed. 1909) which outlined a history of Christianity that was structured around a dynamic theory of historical change driven by charismatic innovators, revolutions and the creative destruction of old orders. To scholars of technical change, particularly those familiar with Harnack's contemporary Schumpeter, this may sound familiar. However, if one looks in more detail, the similarities are so close that this short research note suggests a scholarly investigation of those similarities may be needed which would do much to illuminate the sources of Schumpeter's influential ideas. 
Schumpeter's theory of innovation as outlined in his masterpiece 'Capitalism, Socialism and Democracy', (1942) can be briefly summarised as an evolutionary process by which charismatic entrepreneurs creatively destruct the existing social order and bring about revolutionary changes. However, these changes become routinised over time and a new status quo is established. This routinisation then provides opportunities for new charismatic entrepreneurs to begin a new cycle of innovation. Schumpeter famously argued that the process of innovation itself had undergone a revolution and was becoming routinised as the locus of innovation shifted from charismatic entrepreneurs to the modern managed R\&D process conducted in laboratories. The automatisation of innovation was changing the world as progress became less dependent on leadership and the initiative of individuals. As a consequence, the characteristics needed to rise to a position of power and the characteristics needed to fulfil the role once there are no longer the same. Capitalism, for Schumpeter, therefore creates a frame of mind and style of life incompatible with itself. This Schumpeter argued had major implications for capitalism, socialism and democracy.

In the context of this research note, particular attention should be given to the terminology. The term charisma may seem to modern eyes very Weberian, and Schumpeter uses it in precisely that context. However, the term, while clearly post-Romantic, originates in the New Testament and was popularised in $19^{\text {th }}$ century Europe by Harnack. Weber himself acknowledges his debt to Harnack in a letter of 1906, and interacted with Harnack through their mutual involvement in Die christliche Welt (Liebersohn 1988:88; see Haley, 1980 for the link to Sohm).

Similarly, the German term that Schumpeter uses for 'routinisation' is Veralltäglichung, which has both a sense of 'making routine', as is used by evolutionary economists to explain firm behaviour (i.e., Nelson and Winter, 1982), and also another sense of 'making banal' (Taylor, 2002: 18-19). Both these terms were terms of art at the time and both point to the influence of Harnack.

If we outline Harnack's theory of innovation in the history of Christianity the similarities become clear. Harnack drew on Schleiermacher and argued that religious experience was essentially internal and on Hegel in arguing that this subjective experience evolves through history through a dialectical interaction between subjective experience and objective reality. The original source of religious experience was personal but became social through the actions of charismatic prophets. This prophet was touched by God and creatively destroyed the existing foundations of religious belief by creating a sect that would eventually grow into a religion. However, in the process of growing from a sect into a religion, the original charismatic personal experience of the prophet and his disciples would be reduced as contradictory perspectives become integrated in a Hegelian 
process of dilution. The overall result is that the original religious experience becomes increasingly routinised and the 'white heat' of religious experience shifts to 'dull habit' (Harnack, 1909).

Thus the history of Christianity can be seen as a series of cycles of innovation, creative destruction and routinisation. To simplify hugely, Moses was touched by God, became a charismatic prophet who creatively destroyed the old pagan religion and created a new religious innovation - Judaism. However, Judaism became codified and routinised by the Pharisees as it spread and became institutionalised. In doing so the original message was corrupted into routines and laws rather than experience of God which "made this religion into an earthly trade" (Harnack, 1909, 51).

God then touched a new charismatic prophet - Jesus - who through force of character was responsible for a Nietzschean 'transvaluation of all values' (Harnack 1909, 68) and created a new sect. Through charismatic leadership this new sect - Christianity - creatively destroyed the old routinised Jewish religion and replaced it. The original charismatic leadership was carried on through the Apostles, but gradually the religious texts and practice that had originally inspired Jesus became increasingly banal and routinised under the influence of Hellenic philosophy, and for Harnack especially the influence of St. Paul. Religious experience became further routinised as new doctrine developed in the third, fourth and fifth centuries and then bureaucratized in the medieval Catholic Church. Of particular importance for Harnack was the corruption of trinitarianism and Christology, reflected in new assertions such as Christ dying for Adamic sin, or the notion that God created the world from a void, that had not been part of the original Christian tradition.

The Cappadocian theologians in particular, Gregory of Nyssa, Basil of Caesarea and Gregory of Nazianuzus, had drawn on Greek philosophy to make distinctions between the part of truth that is factual and the part that eludes demonstration. For them, keryma is the public, scriptural codified teaching of the Church, while dogma represents the deeper meaning of religion that can only be experienced and is imperfectly captured in symbolic form. The difference is similar to the difference between reading a musical score and listening to an orchestra. Harnack's works often focused on understanding the history of dogma and the ways in which it was lost by being routinised or (to use an anachronistic term) codified.

The routinisation that followed the establishment of Christianity as the official religion of the Roman Empire continued through to the Middle Ages, to the point that it became increasingly corrupted and divorced from the original experience that had inspired the Apostles. When lay 
spiritual groups emerged, they were integrated into the Church through a process of the "monastization of the laity" where their cloistered lives could be controlled. God then touched a new charismatic prophet - Martin Luther - who through force of character created a new sect that in time creatively destroyed the old routinised Catholic religion and replaced it with a newly purified (Reformed) and uncorrupted Protestantism that removed the Catholic emphasis on moralism, ritualism, and hierarchy. For Harnack the Reformation had only completed part of the job and his life's vocation was to complete the reform process. Harnack saw Christianity as corrupted by its dependence on 'an imagined Christ' and the metaphysical baggage that comes with it. By seeing Christ as a historical figure who had inner knowledge of God, and through that knowledge, understood that his vocation was to spread God's word, Christianity could return to its "unchanging core" that reflected man's "timeless humanity" and the social principles of the Gospels.

The very close similarities in terminology and structure between the works of Harnack and Schumpeter lead to the obvious suggestion that they might be connected. Further circumstantial support can be found by re-reading 'Capitalism, Socialism and Democracy', (1942), and paying close attention to the Harnackian language it contains. The references to Marx as a prophet, and hints that Schumpeter regarded himself as a new prophet of society whose claim to fame would be recognised in the future as displacing the false prophet Marx ${ }^{1}$ suggests that the influence of Harnack's theories extended from Schumpeter's analysis of technical change to his own perception of himself. Future research may wish to consider this possibility, particularly as it has been remarked before that Schumpeter was not known for his modesty.

There are obvious counter-arguments to these suggestions. First, that the Schumpeterian notion of revolutionary change was wide-spread and not confined to intellectual thought derived from Harnack. Burrow (2000) for example, makes it clear that in the $19^{\text {th }}$ century, following the failure of the 1848 revolutions, and the establishment of an increasingly bureaucratised $19^{\text {th }}$ century state, there was a very receptive audience keen to believe in revolutionary change and displacement of corrupt societies. As a theory, creative destruction might therefore have reflected political reality and wide-spread political hopes rather than theological theory. Political revolutions (attempted and successful) were wide-spread during this period - Russia 1917, Spain 1917-1919, Cordoba (Argentina) 1918, Germany 1918, Hungary 1919, Bulgaria and Germany 1923, Indonesia 1926, China 1927, Brazil 1935 (the list could be extended). Many political

\footnotetext{
${ }^{1}$ Schumpeter notes of the success of Marx is indeed attributable to the barrelful of white-hot [a Harnackian term of art] phrases... But he was a prophet, and in order to understand the nature of this achievement we must visualize it in the setting of his own time. It was the zenith of bourgeois realization and the nadir of bourgeois civilisation, and a time of mechanistic materialism, of a cultural milieu which had as yet betrayed no sign that a new art and a new mode of life were in its womb, and which rioted in a most repulsive banality" (5-6)
} 
leaders, Lenin being perhaps the most obvious example, stage-managed their media image to a widely held perception of the importance of charismatic leadership.

In such a period of social change, it does not appear too large a leap to extend ideas from politics (rather than theology) to economics. There is no denying revolutions are important historical phenomena (Halliday, 1999), and that between 1918 and 1923 would have influenced how an Austrian or German academic thought. It is therefore important to be nuanced about any supposed connections, and the argument here is not about intellectual determinism - that Harnack determined Schumpeter's thought - but instead about intellectual influence - that Harnack's theories contained components that influenced Schumpeter.

A second counter-argument might be that such theoretical models of social change are more widespread, and focusing on a connection between Schumpeter and Harnack is misleadingly specific. For example, a similar process of creative destruction can be found in the work of Schumpeter's contemporary the Islamist political philosopher Sayyid Qutb (Musallam, 2005). He argues along Harnackian lines that Moses had been the founder of the original religion as a code of behaviour that became routinised into a rigid ketmatic system. God sent another prophet Jesus, who restored the earlier spiritual religion, but Christianity itself became corrupted as it was routinised first by Pauline Hellenic philosophy, then new Doctrine and then by the paganism of Constantine. The effect of this was to corrupt Christianity through a process of secularisation which ended up creating the schizophrenic society of the $20^{\text {th }}$ century West where life was driven by technology separated from religion. ${ }^{2}$ For Qutb, this early secular confusion led God to select another prophet who founded Islam, but after his death, Islam itself became corrupted and secularised, and entered a period of relative decline that by implication could be turned around by charismatic revolutionary leaders.

Qutb's ideas clearly show that theological ideas about cycles of routinisation and creative destruction are not only to be found in the works of Schumpeter and Harnack and any unmediated connection is probably over-simplistic. However, given the close links between German and Egyptian thought during the 1930s they may also suggest an influence, potentially strengthening the suggestion that Harnack's ideas are more prevalent that has previously been recognised in the non-German speaking academic world.

\footnotetext{
${ }^{2}$ Qutb's source on western secularisation is J. W. Draper's 1874 History of the Conflict between Religion and Science, a nineteenth century rationalist classic that argued that historical progress was driven by science, and at every step progress was held back by religion (Berman, 2004:69). Draper's history has been criticised as a wilfully misleading, politically driven mis-representation of the close historical relationship between Christianity, (and religion more generally), and science (Lindberg and Numbers 1984).
} 
Swatos' (1984) debunking of the supposed religiousity of early American sociologists should caution against to quick a jump to make direct theological connections. However, the suggestion here is not theological, only that Schumpeter may have been influenced by the model of social change. Given Schumpeter's politics it seems unlikely he shared Harnack's wider concerns about either theology or society.

While understanding the minds of historical figures is far from simple, the temporal and institutional links between Harnack and Schumpeter make it unlikely that two such prominent professors would not have known each other's work. Harnack was a very prominent intellectual figure who turned down the job as Ambassador to the United States. It seems very unlikely that Schumpeter did not know of him or of his work, after all, Schumpeter was at Harvard when Harnack was offered, and rejected, a Professorship.

This short research note probably raises more questions than it answers. Harnack's work at least shows that ideas about cycles of creative destruction and charismatic innovation were not only created by Schumpeter. The prominence of Harnack as an intellectual figure, internationally and specifically among the German speaking Harvard Professorial faculty suggests Schumpeter would have known of him. Whether his influence on Schumpeter is direct or not is unclear.

If future research does confirm that these similarities are not co-incidential then it may be that the academic community will need to reread Schumpeter with fresh eyes. It may also suggest a solution to the question of where the theory of creative destruction came from, and lead to a reconsideration of its value. If the theory is derived from a historiographic tradition in theology that has been abandoned there, questions might be raised about how viable it is in a completely different environment. This, in turn, may provide support for the suggestion that technology evolves through a process of 'creative accumulation' rather than creative destruction, and suggest that revolutionary models of technical change that underpin so much public policy may need to be reconsidered (Patel and Pavitt, 1998). ${ }^{3}$

\section{Bibliography}

Burrow, J. W., 2000. The Crisis of Reason. Yale University Press, New Haven. Berman, P (2004) Terror and Liberalism, W W Norton and Company.

Draper, J. A. (1998) Weber, Theissen and "Wandering Charismatics" In The Didache Journal of Early Christian Studies - Volume 6, Number 4, pp. 541-576

Hagglund, B. (2007) History of Theology Concordia: London

Haley, P. (1980), Rudolph Sohm on Charisma, The Journal of Religion, Vol. 60, No. 2, pp. 185-197

${ }^{3}$ See Nightingale and Martin (2004) on the limitations of the biotech revolution model. 
Halliday, F. (1999) Revolution and World Politics: The Rise and Fall of the Sixth Great Power; Palgrave Macmillan

Harnack, A. (1901), The History of Dogma, 7 volumes, Boston Little Press.

Harnack, A. (1909) What is Christianity? Fortress Texts in Modern Theology, Princeton

Harnack, A. (1988). "Stages of Scientific Knowledge" in Adolf Von Harnack: Liberal Theology at its

Height, ed. by Rumscheidt, Martin. London: Collins Liturgical Publications

Libersohm, H., (1988) Fate and Utopia in German Sociology 1870-1932 (Cambridge).

Lindberg R. C., and Numbers R. L. (1986), God and Nature: Historical Essays on the Encounter between Christianity and Science. University of California Press.

Patel, Pari and Pavitt, Keith (1998), 'The Wide (and Increasing) Spread of Technological Competencies in the World's Largest Firms: A Challenge to Conventional Wisdom', in Chandler, A., Hagstrom, P., Solvell, O. (eds.), The Dynamic Firm: The Role of Technology, Strategy,

Organisation and Regions, Oxford: Oxford University Press, 192-213

Musallam A., A., (2005). From Secularism to Jihad: Sayyid Qutb and the Foundations of Radical Islamism.

Westport, Conn.: Praeger.

Nightingale, P and Martin P. (2004) 'The Myth of the Biotech Revolution', Trends in

Biotechnology, Vol.22 No.11 565-569

Rumscheidt, Martin (ed.) 1988. Adolf von Harnack: Liberal Theology at Its Height. London: Collins

Schumpeter, J. (1942) Capitalism, Socialism and Democracy', Pinter, London

Swatos, W. H., (1984), Faith of the Fathers: Science, Religion and Reform in the Development of Early

American Sociology, Wyndam Hall Press

Taylor, C. (2002), Varieties of Religion Today: William James Revisited, Harvard University Press 


\section{Recent papers in the SPRU Working Paper Series:}

SWPS 2013-03. Paul Nightingale and Alex Coad. September 2013. "Muppets and gazelles: political and methodological biases in entrepreneurship research".

SWPS 2013-04. Alberto Marzucchi and Sandro Montresor. September 2013. "The multidimensional additionality of innovation policies. A multi-level application to Italy and Spain".

SWPS 2013-05. Fulvio Castellacci. September 2013. "Institutional voids or entry barriers? Business groups, innovation and market development in emerging economies".

SWPS 2013-06. Tommaso Ciarli and Michele Di Maio. October 2013. "Theoretical arguments for industrialisation-driven growth and economic development".

SWPS 2013-07. William Lazonick, Mariana Mazzucato, and Öner Tulum. October 2013. "Apple's changing business model: what should the world's richest company do with all those profits?".

SWPS 2013-08. Phil Johnstone. October 2013. "Planning reform, rescaling, and the construction of the post-political: The case of The Planning Act 2008 and nuclear power consultation in the UK".

SWPS 2013-09. Mariana Mazzucato and Alan Shipman. October 2013. “Accounting for productive investment and value creation".

SWPS 2013-10. Anders Bornhäll, Sven-Olov Daunfeldt, and Niklas Rudholm. October 2013.

"Sleeping Gazelles: High profits but no growth".

SWPS 2013-11. Alex Coad and Christina Guenther. November 2013. "Processes of firm growth and diversification: theory and evidence".

SWPS 2013-12. Sally Brooks. November 2013. "Investing in Food Security? Philanthrocapitalism, Biotechnology and Development".

SWPS 2013-13. Vicente Salas-Fumás, J. Javier Sanchez-Asin, and David Storey. November 2013. "Entrepreneurs and Output: Theory and Empirical Evidence with Spanish Data".

SWPS 2013-14. Diego Chavarro, Puay Tang, and Ismael Rafols. November 2013. "Interdisciplinarity and research on local issues: evidence from a developing country".

\section{SPRU}

Science and Technology

Policy Research
SPRU

Science and Technology Policy Research

University of Sussex

Falmer, Brighton, BN1 9SL, UK

www.sussex.ac.uk/spru 